Volume 4 Issue 6 May

May 1956

\title{
Other Recent Acquisitions
}

Follow this and additional works at: https://digitalcommons.colby.edu/cq

\section{Recommended Citation}

Colby Library Quarterly, series 4, no.6, May 1956, p.117-120

This Back Matter is brought to you for free and open access by Digital Commons @ Colby. It has been accepted for inclusion in Colby Quarterly by an authorized editor of Digital Commons @ Colby. 


\section{Colby Library Quarterly 117}

I am sorry to answer you so briefly, but I have had much correspondence to attend to owing to my sister's death ${ }^{1}$ a fortnight ago.

Sincerely yours

ThOMAs HaRdy.

000000000

\section{OTHER RECENT ACQUISITIONS}

$\mathrm{D}$ oes the name of Joseph Sheridan LeFand (1814-1873) mean anything to you? Perhaps not, but at one time this Irish journalist and novelist was well known, noted especially for his stories of mystery and dread. When he was in his thirties, he wrote a number of historical novels, such as The Cock and Anchor (1845) and The Fortunes of Colonel Torlogh O'Brien (1847). Twenty years later, however, he turned to the supernatural, and in rapid succession produced The House by the Church-Yard (1863), Wylder's Hand (1864), Uncle Silas (1864), Guy Deverell (1865), and Haunted Lives (1868). In a recent textbook, Cavalcade of the English Novel (1954), Professor Edward Wagenknecht remarks (p. 562) that "LeFanu still awaits the full study his merits demand." A. P. Graves and S. M. Ellis seem to be among the very very few persons who have written about LeFanu. The "full study" that Professor Wagenknecht refers to has been now made much easier at Colby by a gift from Mr. $\mathrm{H}$. Bacon Collamore of the Board of Trustees. He has presented us with an entire LeFanu Collection-fifty-one volumes in all-first editions in their original bindings.

From Mrs. Ellen Plantiff we have received a copy of Hans Christian Andersen's Alphabet, with pictures by Dagmar Starcke (Copenhagen: Thaning and Appel, 1955).

1 Mary Hardy died on or about November 21, I9I5. Her funeral was held on November 29. 


\section{Colby Library Quarterly}

James L. Ross (Colby '36), has sent us three welcome additions to our T. B. Mosher collection: works by Hewlett, by Swinburne, and by Oscar Wilde.

From Mrs. Thomas J. Burrage we have received Copy No. 86 (of an edition limited to 365 copies), of John Pory's Description of Plymouth Colony, edited by Champlin Burrage (Boston, 1918).

To Mr. and Mrs. W. Robert Lombard we are indebted for an interesting addition to our early-seventeenth-century books: John Calvin's Institutio Christianae Religionis, Geneva: Essaiam LePreux, 1612. Ex Libris Frederic Palmer; Ex Libris William E. Lombard (Colby 1893), and Ex Libris W. Robert Lombard (Colby'28).

From Mr. John B. R. Lyons, of Jamaica Plain, Massachusetts, we have received six volumes of Household Words, the Victorian magazine founded and "conducted" by Charles Dickens.

Two members of the Board of Trustees have made unusual gifts to the Library. Mr. Neil Leonard has given us Copy No. $23^{1}$ (of an edition limited to 506 copies) of E. Alfred Jones's The Old Silver of American Churches, Letchworth, England: The Arden Press, 1913; with 145 plates, many of them full-page. And from Mr. H. Bacon Collamore has come a copy of Henry James's The Real Thing (New York: Macmillan, 1893) which is-if we know anything about James bibliography-the real thing. For this copy is evidently the first issue, first state, of the First Edition, with "Copyright 1892" printed on the verso of the title-page. (The second issue reads "Copyright 1893" on a stub; and the third issue reads "Copyright 1893 " not on a stub.) The real thing among James bibliographers will therefore "get quite a kick" out of that ' 92 date.

When Thomas Hardy published his novel, The Hand of Ethelberta, in 1875 , he quoted the Roman poet Lucretius on 


\section{Colby Library Quarterly $\quad 119$}

the title-page. The Colby College Library has now acquired Hardy's copy of Lucretius: On the Nature of Things: London, Henry G. Bohn, 1851. The book contains two translations of Lucretius's Latin: a prose translation by John S. Watson and a translation into English verse by John Mason Good. The latter seems not to have interested Hardy as much as the prose, for he made no comment at all on Good's translation and marked very few passages. One, however (on page $34^{8}$ ), he did mark: a six-line passage that is worth quoting:

\footnotetext{
For, far from mortals and their vain concerns,

In peace perpetual dwell th' immortal gods;

Each self-dependent, and from human wants

Estranged for ever. There no pain pervades,

Nor dangers threaten; every passion sleeps,

Vice no revenge, and virtue draws no boon.
}

In the light of Hardy's Dynasts, fifty years later, it is easy to see how this Lucretian seed sank into fertile soil and grew and blossomed. In the pages devoted to Watson's prose translation, Hardy marked many passages. He underlined words, phrases, and whole sentences. And on at least four pages he wrote brief comments in the margin. Sometimes the point is a mere matter of accuracy in translation (e.g., on page 6 , where the translator rendered Lucretius's $r e$ ligione as "Religion," Hardy wrote in the margin "Theology"; and on page 45, for "though deceived, . . . not injured," Hardy paraphrased: "deceive them into good"), but at other times Hardy was concerned with the thought or the idea in the mind of Lucretius. For example, on page 79 , "Scent penetrates where juices ... do not make a way to the corporeal organs," Hardy underlines juices and writes: "What does the man mean?" On page 224, on the passage: "Many kinds of animal life ... must ... have perished. ... For whatever creatures you see breathing the vital air, assuredly either craft, or courage, or at least activity, has preserved. . . ." Hardy's marginal comment reads: "Survival 


\section{Colby Library Quarterly}

of the Fittest"-a comment obviously written after Hardy had read Darwin's famous work of 1859 .

To Mr. Benton L. Hatch we are indebted for a copy of Thomas Cook's New Universal Letter Writer, Hallowell [Maine]: N. Cheever, 1812: two volumes (with independent pagination) bound in one.

From Miss Mary E. Mulholland, of Los Angeles, California, we have received an extremely pleasant and informative letter which Sarah Orne Jewett wrote her, dated January 23, 1899; it arrives just in time for inclusion in the volume of Jewett letters on which Professor Richard Cary has been engaged for some time-a volume which the Colby College Press hopes to publish in the course of the next twelve months.

To Miss Irene Cooper Willis, of London, the Library is indebted for ten volumes of Hardy's fiction in foreign translations: Under the Greenwood Tree in German and in Japanese; Far from the Madding Crowd in Tamil (Madras, India); The Mayor of Casterbridge in Finnish and in Tamil; Life's Little Ironies in Hungarian; and Tess of the D'Urbervilles in Bengali, in Hungarian, in Japanese, and in Slovak. This group of books reminds us anew of Edwin Arlington Robinson's sonnet "For a Book by Thomas Hardy" in which he talks of seeing (in his home in Gardiner, Maine) "the cottage lights of Wessex beam." How far those cottage lights have thrown their beam!

"In 1443, when Humphrey, Duke of Gloucester, presented seven volumes to the University of Oxford, the ViceChancellor wrote to him: 'This your benefaction to us is, in a peculiar sense, befitting your character and will outlive the transitory fame of all your other exploits.' The ViceChancellor spoke the truth."-Arthur L. Goodhart, Master of University College, Oxford, in an address delivered in California on March 17, 1952. 